\title{
PROBLEM STATUSU TEOLOGII W UJĘCIU DUNSA SZKOTA I TOMASZA Z AKWINU
}

Właściwym tematem pracy jest problem statusu teologii. Próba ustalenia charakteru świętej nauki podjęta zostanie w oparciu o pytanie: „Utrum sacra doctrina sit scientia"1. W polskiej literaturze odnaleźć można prace, w których rozważana jest kwestia statusu teologii również w związku z tym średniowiecznym pytaniem. Tę tematykę odnajdziemy m.in. w artykule Andrzeja Bronka i Stanisława Majdańskiego: Teologia. Próba metodologiczno epistemologicznej charakterystyki ${ }^{2}$ czy - już w tytule bezpośrednio odnoszącym się do tego zagadnienia - tekście Romana Majerana pt. Stanowiska Tomasza z Akwinu $i$ Wilhelma Ockhama wobec zagadnienia: czy teologia jest nauka ${ }^{3}$. Niniejszy tekst, w przeciwieństwie do wymienionych, nie będzie mieć charakteru erudycyjnego. Podjęte zadanie jest znacznie skromniejsze - artykuł stanowić będzie spojrzenie na fragmenty tekstów średniowiecznych filozofów w sposób analityczny, poprzez krytyczne, stricte problemowe i - co trzeba wyraźnie podkreślić - wstępne porównanie poglądów zawartych w pismach Dunsa Szkota i św. Tomasza w kwestii naukowości teologii. Filozofowie ci, wychodząc od podobnych założeń i tej samej definicji Arystotelesa, do-

1 Tak brzmi tytuł drugiego artykułu pierwszej kwestii Summy teologicznej Tomasza z Akwinu.

${ }^{2}$ Zob. A. Bronk, S. Majdański, Teologia. Próba metodologiczno-epistemologicznej charakterystyki, „Nauka” (2006) nr 2.

${ }^{3}$ Zob. R. Majeran, Stanowiska Tomasza z Akwinu $i$ Wilhelma Ockhama wobec zagadnienia: czy teologia jest nauka, [w:] Czasy katedr - czasy uniwersytetów. Źródta jedności narodów Europy, red. W. Sajdek, Lublin 2005. 
szli do odmiennych wniosków. Celem artykułu będzie próba wskazania, w którym momencie i z jakich powodów ich poglądy się rozeszły.

\section{KRYTERIUM NAUKOWOŚCI}

Przede wszystkim należy zauważyć, że zarówno Duns Szkot, jak i św. Tomasz, próbując ustalić status teologii, opierali się na Arysto-

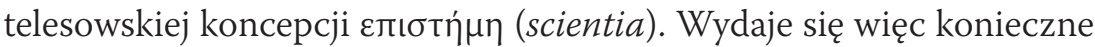
rozpocząć pracę od analizy stosownego fragmentu Analityk wtórych ${ }^{4}$. Zdaniem Arystotelesa wiedza naukowa musi spełniać następujące warunki: ${ }^{5}$

1. Poznanie naukowe ma charakter pewny, dedukcyjny, bez możliwości błędu (co gwarantują kolejne warunki).

2. Poznanie to obejmuje przyczynę istnienia rzeczy (jedyną, całkowitą, bezwarunkową i konieczną).

3. (a) Przedmiot poznania naukowego stanowi to, co „nie może być inne, niż jest"; (b) wiedza ta dotyczy elementu istotnego natury przedmiotu; (c) poznany atrybut przedmiotu musi przysługiwać ogółowi jego desygnatów.

4. Punktem wyjścia rozumowania są przesłanki przyjęte bez dowodzenia jako zasady konieczne i oczywiste.

5. Poznanie zachodzi przy pomocy sylogizmu o prawdziwych przesłankach, „pierwotnych, [...] lepiej znanych, wcześniejszych [od wniosku]"7, czyli przyczyn rzeczy. Taki sylogizm nazywamy dowodem.

${ }^{4}$ Zob. Arystoteles, Analityki wtóre, ks. I, 2-4; 71b-74a. Korzystam z wydania: Arystoteles, Analityki pierwsze i wtóre, przeł. K. Leśniak, Warszawa 1973.

${ }^{5}$ Wprowadzony podział na pięć głównych warunków jest odautorski.

6 To pojęcie precyzuje w I, 4; 73a: „coś, co jest prawdziwie orzekalne o wszystkich faktach - [...] zawsze, a nie tylko w tym czy innym czasie [...]”.

7 Arystoteles wprowadza podział tego, co „wcześniejsze” i „lepiej znane”, na: „dla nas...” i „z natury.... Tutaj uściśla: „[... ] w sensie bezwarunkowym «wcześniejszym» i «lepiej znanym» nazywam coś, co się znajduje z dala od zmysłowych spostrzeżeń. Najdalej od zmysłowych spostrzeżeń jest to, co ogólne [...]”. Arystoteles, Analityki..., dz. cyt., $72 a$. 
Arystoteles wymienia też wiele innych właściwości wiedzy naukowej", które jednak wydają się wtórne wobec wyżej wymienionych i, co najważniejsze, nie odnoszą się do nich w sposób bezpośredni ani Tomasz, ani Szkot, o czym będzie mowa dalej.

Przy omawianiu zagadnienia naukowości teologii ważne jest, by nie ulec pokusie mieszania kilku kwestii: relacji rozum-wiara i teologia-metafizyka, z zasadniczą: czy teologia jest nauką w rozumieniu Arystotelesa? Wszystkie trzy nieuchronnie łączą się ze sobą, ale nie są tożsame. Równie łatwo jest przeinaczyć postawione pytanie na: „czy teologia zasługuje na miano nauki?". Sformułowanie z I, 1, 2 Tomaszowej Summy nie kwestionowało w żadnym razie wartości teologii - z pewnością dywagacji na ten temat nie snułby ani Tomasz, ani Duns Szkot, ani żaden inny wybitny scholastyk. Pytanie oznaczało już raczej obniżenie rangi poznania teologicznego do stricte naukowego. Jak zauważa Tomasz Polak:

Kiedy w okresie dojrzałej scholastyki [...] pytanie o naukowość teologii postawiono po raz pierwszy w tej właśnie formie, wartość teologii nie była przez nikogo kwestionowana. Pytano więc właściwie o to, czy poznanie teologiczne można umieszczać na tej samej płaszczyźnie z innymi dziedzinami poznania $[\ldots]^{9}$.

Ponadto zagadnienie naukowości teologii nie dotyczyło rozumności samej wiedzy o Bogu (w którą nikt nie wątpił), a racjonalności ludzkiego poznania. Roman Majeran pisze, że:

${ }^{8}$ M.in. unikanie błędnego koła; nieprzenoszenie dowodu z jednego rodzaju na inny; wymóg, aby przedmiotem dowodu były tylko związki wieczne; ponadto przesłanki dowodu muszą być właściwe danej nauce, a ciąg przesłanek nie może być nieskończony i wiele innych. Zob. Arystoteles, Analityki..., dz. cyt., ks. I.

9 Wypowiedź Tomasza Polaka (Węcławskiego) z: T. Dzidek, Bt. Jan Duns Szkot, http://www.opoka.org.pl/biblioteka/T/TD/mistrzowie/bl_jan.html (30.10.2015). 
[p]ytanie o to, czy dyscyplina uprawiana na fakultetach teologicznych średniowiecznych uniwersytetów jest nauką, jest [...] pytaniem, [...] czy wiedza zbawcza [...] jest jednocześnie najdoskonalszym rodzajem poznania, do jakiego zdolna jest istota zarazem rozumna i zmysłowa, jaką jest człowiek [...]; może to, co dla człowieka jest doskonałością, w perspektywie absolutnej okazuje się czymś bardzo ułomnym i względnym ${ }^{10}$.

Tak więc wiedza o Bogu - którą posiada sam Bóg - jest racjonalna i zgodna z prawidłami Boskiego rozumu, lecz nie wiadomo, czy poznanie Boga przez człowieka jest zgodne z zasadami racjonalności i czy opisane przez Stagirytę struktury ludzkiego rozumu, obowiązujące w poznaniu pozateologicznym, chociaż zbliżają się do charakteru Boskiego, ostatecznego i koniecznego. Odpowiedź pozytywna na pytanie: „czy wiedza święta jest nauką?", oznaczałaby więc niewątpliwe podniesienie rangi dowodzenia za pomocą sylogizmu, natomiast odpowiedź negatywna umniejszałaby wartość nauki i ludzkiego rozumu, a nie - teologii. Warto jeszcze dodać, że podczas gdy Tomasz i Duns Szkot, rozpatrując status teologii, ewidentnie posługiwali się ścisłym rozumieniem zakresu nauki, to już pod koniec XIII wieku, by obronić jej naukowość, zaczęto posługiwać się szerokim ujęciem wiedzy naukowej, wedle którego była to każda wiedza prawdziwie stwierdzająca pewien stan rzeczy ${ }^{11}$. Przy takim rozumieniu ani Tomasz, ani Duns nie zaprzeczyliby naukowemu charakterowi teologii.

Przejdę teraz do analizy stanowisk Tomasza z Akwinu i Jana Dunsa Szkota w kwestii statusu teologii w kontekście przytoczonej definicji Arystotelesa, by następnie zestawić ze sobą te dwa poglądy i podjąć

${ }^{10}$ R. Majeran, Stanowiska..., dz. cyt., s. 189.

11 „[termin scientia] szeroko rozumiany oznaczał jakąkolwiek wiedzę, sąd prawdziwie stwierdzający pewien stan rzeczy [...]. W ścisłym sensie scientia była to wiedza [...] spełniająca najwyższe standardy pewności i konieczności. [...] W ostatniej ćwierci XIII w. nawet zwolennicy św. Tomasza byli raczej ostrożni w przypisywaniu wiedzy teologicznej statusu nauki [...] w ścisłym sensie”. R. Majeran, Stanowiska..., dz. cyt., s. 182 i 197. 
próbę ustalenia, w którym punkcie i z jakich przyczyn ich rozumowania się rozeszły.

\section{ODPOWIEDŹ ŚW. TOMASZA NA PYTANIE \\ O NAUKOWOŚĆ TEOLOGII}

Odpowiedzi twierdzącej na pytanie: „Utrum sacra doctrina sit scientia” udziela Tomasz w artykule o takim tytule ${ }^{12}$. Jego rozważania skupiają się na warunku oczywistości przesłanek (pkt 4. we wprowadzonym podziale) i ogólności przedmiotu nauki (3 c). Co do drugiego z wymienionych warunków, przytoczony zarzut brzmi: przedmiotem wiedzy świętej są jednostki, na przykład dzieje poszczególnych proroków. Wydaje się więc, że święta wiedza nie jest nauką. Na pomoc Tomaszowi przychodzi cytat z traktatu O Trójcy Świętej Augustyna: „przypisuje się tej nauce to tylko, co rodzi, żywi, broni i umacnia zbawienną wiarę"13. W dodatku Tomasz zauważa, że samo rozprawianie o jednostkach nie ma charakteru koniecznego - nie stanowi metody świętej nauki, jej narzędzia, a jedynie wspomaga przekaz treści teologiczno-moralnych pouczanym. A zatem nie ma powodu, by uważać, że charakter przedmiotu nauki nie jest zgodny z warunkiem stawianym przez Arystotelesa. Wykazanie spełnienia kryterium oczywistości okazuje się jednak trudniejsze. Wydaje się, że przesłanki sacrae doctrinae nie są oczywiste, bo punktem wyjścia tej wiedzy jest wiara; a więc nie można mówić o powszechnej zgodzie co do pierwotnych zasad, gdyż - jak czytamy w Liście do Tesaloniczan „nie wszyscy mają wiarę” (2 Tes 3, 2). Czy można jednak jako dowód zamykający problem powołać się na wiedzę Tego, dla którego te zasady są oczywiste? Tomasz wskazuje na przykłady innych nauk, które opierają się na czymś w rodzaju autorytetu: optyka nie zaistniałaby bez zasad

${ }^{12}$ Tomasz z Akwinu, Summa teologii, I, 1, 2. Korzystam z wydania: Tomasz z Akwinu, Traktat o Bogu. Summa teologii, kwestie 1-26, przeł. G. Kurylewicz, Z. Nerczuk, M. Olszewski, Kraków 1999.

13 Św. Augustyn, O Trójcy Świętej, XIV, 1. 
geometrii, muzyka - bez arytmetyki itd. Tak też przesłanki teologii możemy - jego zdaniem - przyjąć jako zasady objawione przez Boga. Boża wiedza o sobie samym i wiedza zbawionych o Nim byłaby dla teologii analogicznie tym, czym każda inna nauka nadrzędna dla podporządkowanej. Pozostaje jednak pytanie: dlaczego wiarygodność Objawienia jest oczywista tylko dla niektórych? Z „winy” Boga, treści objawionych, metody poznania czy samych poznających?

W kolejnym artykule ${ }^{14}$ Tomasz rozważa, czy wiedza święta jest jedną nauką. Problem jest istotny w perspektywie zestawienia poglądów na naukowość teologii Akwinaty i Szkota. Tomasz przytacza zdanie Arystotelesa: ,jedna nauka dotyczy przedmiotu jednego rodzaju” ${ }^{15}$. Wydaje się, że Stwórca i stworzenie to dwa przedmioty dwóch rodzajów. Podstawę odpowiedzi Tomasza stanowi twierdzenie, że teologia mówi w sposób konieczny o Bogu, a o stworzeniu - tylko ze względu na poznanie Boga. Przedmiotem wiedzy świętej jest po prostu ten fragment wiedzy Boskiej, który został objawiony (co odnosi się zarówno do Stwórcy, stworzenia, cielesności, aniołów, zasad postępowania itd.), a przyczynkiem do uzasadnienia tego stanowiska stały się dla Tomasza słowa z Księgi Mądrości: „[Mądrość] dała znajomość rzeczy świętych” $(\text { Mdr } 10,10 a)^{16}$. W dalszych artykułach tejże kwestii $(\mathrm{I}, 1)$ Tomasz rozważa kolejne aspekty statusu teologii, takie jak: praktyczność (art. 4), wyższość nad innymi naukami (5), metodę (8) i inne, które choć ważne, nie wnoszą niczego do zestawienia stanowisk Tomasza i Dunsa Szkota.

\section{STANOWISKO DUNSA SZKOTA W KWESTII STATUSU TEOLOGII}

Jan Duns Szkot na pytanie o naukowość wiedzy świętej najpierw daje odpowiedź jednoznacznie negatywną (gdyż „Wiara nie może współistnieć

${ }^{14}$ Tomasz z Akwinu, Summa..., dz. cyt., I, 1, 3.

15 Tomasz cytuje niedosłownie. Zob. Arystoteles, Analityki..., ks. I, 28; 87a.

${ }^{16}$ Różnicę w zakresach nadrzędnej samowiedzy Boskiej i przedmiotu podrzędnej świętej nauki podkreśla zaś m.in. Syr 3, 21-24. 
z nauką w sensie ścisłym" ${ }^{17}$ ), by następnie przypisać teologii status nauki sui generis. Odwołując się do Analityk wtórych, Szkot przytacza cztery warunki nauki w sensie ścisłym (1, 3a, 4 i 5 we wprowadzonym podziale):

Twierdzę, że nauka w ścisłym znaczeniu musi spełniać cztery warunki, a mianowicie: musi być poznaniem pewnym bez możliwości błędu lub wątpienia; po drugie, musi dotyczyć rzeczy koniecznych (cognitum necessarium), a nie przygodnych (contingens); po trzecie, musi wywodzić się z przyczyny oczywistej dla intelektu; po czwarte, musi być wyprowadzana z zasad oczywistych za pomocą sylogizmu czy wywodu sylogistycznego ${ }^{18}$.

W odniesieniu do tych warunków Duns zgadza się, że teologia jest poznaniem bez możliwości błędu (1) i nie widzi przeszkód w stosowaniu sylogizmów jako pewnej metody dedukcyjnej (5), gdyż: „Teologia jest nauką o prawdach zawartych w Piśmie Świętym i o tych, które można z niego wyprowadzić drogą systematycznej dedukcji"19. Problemy pojawiają się w przypadku dwóch środkowych warunków: koniecznego charakteru istnienia jej przedmiotu (3a) i oczywistości pierwszych przyczyn $(4)^{20}$. Zacznijmy od ostatniego problemu. Wydaje się, że Objawienie nie jest ukazaniem się nam Boga, lecz przedstawieniem człowiekowi Boskiej wiedzy o sobie samym. Zdanie: „Istnieje jeden Bóg w trzech Osobach”, nie prowadzi przecież do żadnych wyobrażeń ${ }^{21}$. Znaleźć tu można pewną zbieżność poglądów obu scholastyków: teolog poznaje przede wszyst-

${ }^{17}$ Op. Ox. 3 d. 24 q.un. n. 15; XV, 48a., [w:] L. Veuthey, Jan Duns Szkot. Myśl teologiczna, przeł. M. Kaczyński, Niepokalanów 1988.

${ }_{18}$ Ord. Prol. p. 4 q. 1-2 n. 208; I, 141., [w:] L. Veuthey, Jan Duns Szkot..., dz. cyt.

19 Ord. Prol. p. 3 q. 1-3 n. 204; I, 138., [w:] L. Veuthey, Jan Duns Szkot..., dz. cyt.

${ }^{20}$ Obydwie kwestie zostały omówione u Tomasza: druga przy analizie I, 1, 2; pierwsza pośrednio, przy rozważaniu jego stanowiska w kwestii jedności świętej nauki (I, 1, 3).

${ }^{21}$ Metafora z 1 Kor 13, 12 mogłaby chyba obrazować ten właśnie podział na poznanie Boga i poznanie wiedzy o Bogu: „Teraz widzimy jakby w zwierciadle, niejasno; wtedy zaś zobaczymy twarzą w twarz. Teraz poznaję po części, wtedy zaś poznam tak, jak i zostałem poznany". Samopoznanie człowieka nie jest potrzebne do poznania go przez Boga. 
kim to, co Bóg wie o sobie samym - to stanowi główny przedmiot świętej wiedzy. Skąd więc odmienność stanowisk końcowych?

Żeby odpowiedzieć na to pytanie, należy przede wszystkim zauważyć, że czym innym jest wiedza Boga o sobie (tej przedmiotem jest sam Poznający), a czym innym - ludzkie poznanie tej wiedzy, czyli nasza teologia. Choć celem teologii człowieka jest wierne odtworzenie samowiedzy Boga, to jednak - nawet gdyby udało mu się to urzeczywistnić - ludzka teologia nie byłaby tym samym, co teologia sama w sobie, ponieważ Bóg opiera się na oczywistości własnego bycia, człowiek zaś jedynie w nie wierzy. Gdyby nawet człowiek wiedział o Bogu wszystko, to wciąż ludzka teologia nie byłaby „teologią Boga"22. Duns Szkot naucza, podobnie jak inni scholastycy, o trzech rodzajach teologii: 1. teologii samej w sobie, 2. teologii świętych, oraz 3. teologii ludzi na Ziemi. Problem wiedzy świętych o Bogu zostanie pominięty, jako że Tomasz nie wykorzystywał jej w żadnym dowodzie w sposób konieczny, Duns zaś wyraźnie sprzeciwiał się jakiemukolwiek wykorzystywaniu jej w dedukcji ${ }^{23}$.

Słowem: Tomasz, określając teologię jako naukę, a jej przesłanki jako oczywiste, wydaje się mówić mimo wszystko o teologii samej w sobie jako punkcie docelowym naszej teologii. Duns Szkot, wręcz przeciwnie, odnosi się jedynie do teologii ludzkiej ${ }^{24}$. Czyżby w ten sposób za-

${ }^{22}$ Zob. L. Veuthey, Jan Duns Szkot..., dz. cyt., s. 25.

${ }^{23} \mathrm{~Np}$. „Poznanie świętych nie jest przedmiotem naszej nauki w ten sposób, żeby dawało nam poznanie Boga jednego i troistego". Op. Ox. 3 d. 24 q. un. n. 4; XV, 38 a., [w:] L. Veuthey, Jan Duns Szkot..., dz. cyt.; „Nie ma żadnego związku przyczynowo-skutkowego między wizją świętych a naszą teologią. [Obrońcy nauki podporządkowanej] przeczą sobie nawzajem; z jednej strony twierdzą, że nauka nie może współistnieć z wiarą; z drugiej powiadają, że - jako nauka podporządkowana - zależy od wiary; więc według nich współistnieje i nie współistnieje z wiarą; a więc zaprzeczają sobie”. Op. Ox. Prol. q. 1n. 30; XIII, 192; Ord. I, 148., w: L. Veuthey, Jan Duns Szkot..., dz. cyt.

24 „Teologia rozważana jako dyscyplina zajmująca się Bogiem w Nim samym jest zatem nauką samą w sobie, choć nie dla nas, ponieważ pomimo konieczności przedmiotu jej dane przyjmowane są na wiarę. Teologia wszakże jako dyscyplina zajmująca się zewnętrznymi działaniami Boga traktuje o «tym, co przygodne», to znaczy o wydarzeniach niekoniecznych, tym samym więc nie jest nauką w tym sensie”. F. Copleston, 
przeczał naukowości wszelkich nauk podporządkowanych, po ich bezpodstawnym oderwaniu od nadrzędnych zasad? Można argumentować za Tomaszem na przykład w ten sposób: stosunek tych dwóch teologii jest jak relacja między arytmetyką a muzyką: ,jak muzyka wierzy w zasady podane jej przez arytmetyka, tak nauka święta wierzy w zasady objawione jej przez Boga"25. Jednakże podczas gdy każdy muzyk ma dostęp do poznania arytmetyki, tak teologia z założenia musi być oderwana od nadrzędnej jej teologii samej w sobie. Po bezpośrednim udostępnieniu wiedzy Boga o sobie samym na nic by się zdało poznawanie Go w przygodnym świecie; dlatego święci nie muszą się już w nim znajdować. Stąd określenie teologii przez Dunsa jako nauki sui generis, z czym wydaje się, że mógłby się zgodzić i Tomasz. To wszystko odnośnie do punktu 4.

Trudno byłoby w tym miejscu pominąć artykuł, w którym Tomasz pisze explicite, że to Bóg jest przedmiotem teologii. W tym kontekście należy zaznaczyć, że Duns z kolei określa Boga jako jej cel ostateczny. Wiąże się z tym nieporuszana wcześniej kwestia konieczności przedmiotu nauki teologicznej (3a). Duns Szkot twierdzi wszak, że teologia zajmuje się nie tylko tym, co konieczne (Bóg), ale i tym, co przygodne. Co więcej, uściśla, że przedmiotem wiedzy człowieka nie może być Bóg jako Bóg, gdyż „Żadna wiedza zdobyta drogą naturalną nie może dotyczyć Boga rozpatrywanego w aspekcie jego Bóstwa"26 - teologowie poznają jedynie Boskie atrybuty. Teologia mówi o tym, co poznajemy dzięki Objawieniu. Reasumując, jeśli chodzi o sedno tego problemu: 1) zdaniem Tomasza teolog poznaje świat jedynie o tyle, o ile przez niego może poznać Boga; 2) według Dunsa skoro w ogóle poznajemy ten świat, a nie jest on konieczny i - wbrew definicji nauki Arystotelesa ${ }^{27}$ - mógłby być

Historia filozofii, t. II: Od Augustyna do Szkota, przeł. S. Zalewski, Warszawa 2ooo, s. 561.

${ }^{25}$ Tomasz z Akwinu, Summa..., dz. cyt., I, 1, 2.

${ }^{26}$ Rep. Par., Prol. q. 3 a. 1; XXII, 47 a., [w:] L. Veuthey, Jan Duns Szkot..., dz. cyt.

27 „[...] to, co stanowi przedmiot wiedzy bezwarunkowej, nie może być inne niż jest". Arystoteles, Analityki..., dz. cyt., ks. I, 2; 71 b. 
inny niż jest, to nie cały przedmiot teologii jest konieczny; ergo: teologia nie jest nauką. Próbując rozwiązać ten problem, przede wszystkim należy ustalić, co każdy z nich uważał za właściwy przedmiot teologii. Duns twierdzi, co następuje:

1. Nie można poznać Boga w aspekcie Jego Bóstwa ${ }^{28}$

2. Pierwszym przedmiotem teologii jest cel ostateczny ${ }^{29}$.

3. Celem teologii jest radowanie się miłością ${ }^{30}$.

4. Przedmiotem naszej teologii jest Bóg jako byt nieskończony ${ }^{31}$

5. Nieskończone jest niepoznawalne (cyt. z Arystotelesa) ${ }^{32}$.

6. Teologia jest nauką o prawdach zawartych w Piśmie Świętym ${ }^{33}$

28 „Rep. Par., Prol. q. 3 a. 1; XXII, 47 a., [w:] L. Veuthey, Jan Duns Szkot..., dz. cyt.

29 „Pierwszym przedmiotem teologii jest cel ostateczny; zasady, które do niego prowadzą, są zasadami praktycznymi; zasady teologii są więc zasadami praktycznymi, jak i wnioski, które się z nich wyprowadza”. Ord. Prol. n. 314; I, 208., [w:] L. Veuthey, Jan Duns Szkot..., dz. cyt.

30 „Utrzymujemy, że teologia jest naprawdę praktyczna ze względu na cel, do jakiego poznanie powinno naturalnie zdążać; oto dlaczego twierdzimy, że poznanie, ze względu na cel, którym jest radowanie się miłością, jest szlachetniejsze niż wszelkie poznanie spekulatywne”. L. Veuthey, Jan..., dz. cyt., n. 353; I, 229.

31 „Bóg, jako byt nieskończony jest przedmiotem naszej teologii. Nie mówi ona o nim tego, co możemy poznać rozumem przyrodzonym, jak mądrość, dobroć itd., gdyż te atrybuty mogą być poznane dzięki filozofii, ale o tym, co poznajemy dzięki Objawieniu, jak: Bóg jest jeden w trzech Osobach". Ord. I Prol. p. 2 q. 1-3 n. 88; XVI, 32., [w:] L. Veuthey, Jan Duns Szkot..., dz. cyt.

32 „[...] w II księdze Metafizyki [Arystoteles mówi]: „nie można poznać nieskończonej ilości rzeczy”; zatem także bytu nieskończonego, ponieważ tym samym wydaje się brak proporcji intelektu skończonego do czegoś nieskończonego, jak i do nieskończonej ilości rzeczy, jako że w podobnej lub przynajmniej niemniejszej mierze to, co nieskończone przekracza możliwości poznawcze naszego intelektu”. Jan Duns Szkot, Wiedza człowieka o Bogu [Opus Oxoniense, I. dist. III, q. 1], przeł. M. Gensler, D. Gwis, E. Jung-Palczewska, [w:] Wszystko to ze zdziwienia. Antologia tekstów filozoficznych $z$ XIV wieku, przeł. M. Gensler, D. Gwis, E. Jung-Palczewska, red. E. Jung-Palczewska, Warszawa 2000, s. 34.

33 „Teologia jest nauką o prawdach zawartych w Piśmie Świętym i o tych, które można z niego wyprowadzić drogą systematycznej dedukcji”. Ord. Prol. p. 3 q. 1-3 n. 204; I, 138., [w:] L. Veuthey, Jan Duns Szkot..., dz. cyt. 
7. Można poznać istotę Boga, ale nie w życiu doczesnym ${ }^{34}$.

W tym zestawieniu niektórzy dopatrują się pewnych sprzeczności. Jak mówi Piotr Sikora:

Teologia obejmuje tak cel ostateczny, jak i środki, które do niego prowadzą. Pierwszym przedmiotem jest cel, czyli jest bardziej spekulatywna, bo zasady są celem drugim. [...] Tomasz jest bardziej logiczny. Duns Szkot mówi, że pierwszym przedmiotem jest cel, a zasady są praktyczne, więc zasady teologii, jak i wnioski są praktyczne. Jest to sprzeczne z uznaniem za główny przedmiot celu. Wychodzi na to, że głównym przedmiotem są zasady, jak dojść do celu ostatecznego. [...] Niepotrzebnie więc pisze, że cel jest pierwszym przedmiotem. Raczej są nim zasady prowadzące do celu ${ }^{35}$.

Wydaje się jednak, że rozpatrywanie wszystkich siedmiu twierdzeń łącznie tworzy pewien spójny obraz tego, jak Duns Szkot pojmuje przedmiot teologii. Do tego konieczne jest jednak przypomnienie, że pod jednym terminem „teologia” kryły się w okresie scholastyki trzy nauki: wiedza Boga o sobie, wiedza świętych o Nim i ziemska teologia. Do natury Boga należy poznawanie siebie; co oczywiste, nie byłoby wiedzy Boga o sobie, gdyby nie było Boga. Stąd - przynajmniej u Dunsa wydaje się wynikać zamienne stosowanie dwóch pojęć w ujmowaniu przedmiotu teologii. Ze zdania trzeciego wynika bowiem, że ostateczny cel teologii (w rozumieniu ogólnym) jest dostępny po śmierci, co potwierdza zdanie siódme. Właściwą dla człowieka teologią jest teologia zbawionych, ziemska ma za zadanie jedynie do niej doprowadzić. Utwierdza to zestawienie zdań 4) i 5). Nasza teologia jest z założenia nie do zrealizowania, a jednak konieczna, by doprowadzić poprzez

\footnotetext{
34 „[...] twierdzę, że szczegółowe i właściwe naturalne poznanie Boga za pomocą właściwego dla Jego istoty pojęcia tak, jak ono w Nim występuje, nie jest dane człowiekowi w życiu doczesnym”. Jan Duns Szkot, Wiedza..., dz. cyt., s. 44.

${ }^{35}$ P. Sikora [w:] T. Dzidek, Błogostawiony..., dz. cyt.
} 
studium Pisma Świętego ${ }^{36}$ do wyższej teologii. Słowem: docelowym przedmiotem naszej teologii jest wiedza o Bogu (zamiennie: sam Bóg). Charakter tej nauki jest więc konieczny. Gdy Duns Szkot odmawia teologii charakteru naukowego, mówi najwyraźniej o naszej teologii, której przedmiotem jest to, co dla nas niepoznawalne. Stąd ograniczenie do praktyczności tejże, co sprowadza się do studium zasad postępowania obowiązujących na tym świecie jako niekoniecznym. Wówczas przedmiot teologii, jako przygodny, nie pozwala określić jej mianem scientia. Przedmiot teologii Boskiej jest zaś w sposób oczywisty konieczny, a ona sama jest nauką.

Sytuacja w pierwszej kwestii Summy Tomasza wydaje się analogiczna. Tomasz stawia pytanie: „Czy Bóg jest przedmiotem teologii?”37, i odpowiada na nie pozytywnie. Z tego można by wyciągnąć pochopny wniosek, że ów przedmiot jest konieczny, teologia jest nauką, a stanowiska Dunsa Szkota i Akwinaty - faktycznie sprzeczne. Tomasz jednak, tak samo jak Szkot ${ }^{38}$, precyzuje, że istota Boga jest dla nas tymczasowo niepoznawalna ${ }^{39}$. Nie wiemy, czym Bóg jest, a ponieważ nie da się stwierdzić, że coś jest, nie mając jego pojęcia ${ }^{40}$, stąd Boga poznajemy

${ }^{36}$ Warto zauważyć, że aż do XII wieku miast używać terminu „teologia”, częściej mówiono o „badaniu Pisma Świętego”. Zob. G. R. Evans, Filozofia i teologia w Średniowieczu, przeł. J. Kiełbasa, Kraków 1996, s. 24n.

37 Tomasz z Akwinu, Summa..., dz. cyt., I, 1, 7.

38 „[...] twierdzę, że szczegółowe i właściwe naturalne poznanie Boga za pomocą właściwego dla Jego istoty pojęcia tak, jak ono w Nim występuje, nie jest dane człowiekowi w życiu doczesnym”. Jan Duns Szkot, Wiedza..., dz. cyt., s. 44.

39 „Zgodnie ze słowami Filozofa z I księgi Analityk wtórych w każdej nauce powinno się określić, czym jest jej przedmiot. Ale owa nauka [teologia] nie określa, czym jest Bóg. Jan z Damaszku powiada bowiem: „nie można powiedzieć o Bogu, czym jest”. Tomasz z Akwinu, Summa..., dz. cyt., I, 1, 7.

${ }^{40}$ Podobnie pisze Szkot: „nie trzeba koniecznie dokonywać rozróżnienia poznania na poznanie «czym jest» poznanie i «czy jest» [...]. Nigdy bowiem nie poznaję jakiejś rzeczy jako czegoś istniejącego, jeśli nie posiadam pojęcia tej rzeczy, któej bycie poznaję [...]”. Jan Duns Szkot, Wiedza człowieka o Bogu, dz. cyt., s. 35n. 
przez skutki Jego działań ${ }^{41}$. Bóg działa w sposób wolny, a więc działania Jego są niekonieczne ${ }^{42}$. Analogii tego twierdzenia do stanowiska Szkota chyba nie ma potrzeby uzasadniać.

\section{ZESTAWIENIE STANOWISK}

Podsumowując, tematem pracy była próba odpowiedzi na pytanie o status teologii poprzez porównanie stanowisk Tomasza z Akwinu i Jana Dunsa Szkota. Na pytanie: „Utrum sacra doctrina sit scientia” pierwszy dał odpowiedź jednoznacznie pozytywną, określając ją jako czcigodniejszą od innych nauk ${ }^{43}$, drugi zaś - negatywną, nadając jej ostatecznie status nauki sui generis. W artykule założono, że skoro obaj opierali się na tej samej definicji nauki, żyli w podobnym czasie i myśleli w sposób spójny, logiczny i obejmujący całość zagadnienia, ich stanowiska nie mogły się różnić w sposób tak skrajny. W świetle definicji Arystotelesa widoczne stało się, że poróżniła ich kwestia oczywistości i konieczności przedmiotu teologii. Poprzez analizę kwestii pierwszej Summy i odpowiednich fragmentów pism Dunsa Szkota, podjęta została próba wykazania, że używając jednego pojęcia „teologia”, Duns położył akcent na naszą teologię, Tomasz zaś mówiąc o teologii „naszej”, traktował ją jedynie jako wstęp do teologii zbawionych. Wydaje się, że wyjaśnia to w pewnym stopniu rozbieżność zdań w tej kwestii tych dwóch myślicieli, choć z pewnością nie zamyka jej w sposób ostateczny.

41 „[...] chociaż o Bogu nie możemy wiedzieć, czym jest, to jednak w tej wiedzy zamiast definicji posługujemy się skutkami jego działań w porządku natury albo łaski zależnie od tego, co mówi się o Bogu w tej wiedzy" - Tomasz z Akwinu, Summa..., dz. cyt., I, 1, 7 .

${ }^{42}$ O tym rozważa Tomasz np. w Summa..., dz. cyt., I, 19, 1-12.

43 „[...] święta wiedza przewyższa inne nauki kontemplacyjne [...]. [...] owa nauka jest pod każdym względem godniejsza od innych”. I, 1, 5. „[...] wiedza święta jest spośród wszystkich mądrości ludzkich w najwyższym stopniu mądrością". I, 1, 6. 


\section{IS THEOLOGY A SCIENCE? THE POSITIONS OF DUNS SCOTUS AND THOMAS AQUINAS}

SUMMARY

The article tries to answer the question of the status of theology by collating Thomas Aquinas' with John Duns Scotus' views. Whereas Thomas Aquinas' answer to the question: Utrum sacra doctrina sit scientia is unambiguously positive and recognizes "the holy knowledge" as the more honourable than other sciences, Scotus' answer is negative, at best giving it the status of science sui generis. In the light of Aristotle's definition, it becomes clear that the two medieval philosophers differed on the question of obviousness and necessity of the subject of theology. An analysis of the first Questio of Summa Theologiae and of the relevant excerpts of Scotus' writings show that Duns emphasized the "earthly theology", whereas Thomas by "our theology" understood a mere introduction to the theology of the saved people. Consequently, the differences between Thomas' and Scotus' views on theology, thus often accented, appearto be illusory.

KEYWORDS

philosophy of theology, the status of theology, theology as a science, Thomas Aquinas, John Duns Scotus 